\begin{tabular}{|c|c|c|c|c|}
\hline Share: Social Work Jurnal & VOLUME: 10 & NOMOR: 2 & HALAMAN: $127-141$ & $\begin{array}{r}\text { ISSN: 2339-0042 (p) } \\
\text { ISSN: 2528-1577 }(e) \\
\text { DOI: 10.24198/share.v10i2.30637 }\end{array}$ \\
\hline
\end{tabular}

\title{
BANDUNG CREATIVE CITY FORUM(BCCF) SEBAGAI PENGGERAK GENERASI MILENIAL DALAM MENCIPTAKAN PERUBAHAN DI KOTA BANDUNG
}

\author{
Romayana Sari Lumbantoruan'1, Nandang Mulyana², Meilanny Budiarti \\ Santoso 3 \\ ${ }^{1}$ Program Studi Kesejahteraan Sosial FISIP - UNPAD \\ 2,3 Pusat Studi CSR, Kewirausahaan Sosial dan Pengembangan Masyarakat
}

romayana09@gmail.com¹, nandang.mulyana@unpad.ac.id², meilannybudiarti13@gmail.com³

\begin{abstract}
ABSTRAK
Generasi milenial memiliki peranan yang penting dalam melakukan perubahan terhadap lingkungan sekitarnya. Tidak dapat dipungkiri, kertelibatan generasi milenial dalam mengisi pembangunan dengan menciptakan peluang dan perubahan positif memiliki dampak yang besar bagi masyarakat. Perubahan yang dicipatakan oleh generasi milenial sangat jelas dirasakan dan tampak dalam bidang ekonomi dan bisnis, di mana perubahan terjadi dengan sangat cepat, sehingga menciptakan ketidakpastian tidak hanya dalam bidang ekonomi dan bisnis saja, melainkan juga di berbagai bidang kehidupan lainnya. BCCF merupakan komunitas mandiri yang fokus mendorong dan menggerakkan generasi milenial dalam menciptakan perubahan melalui upaya pengembangan industri kreatif di Kota Bandung. Ditinjau dengan menggunakan konsep strength prespective, generasi milenial dapat lebih memahami diri mereka, dan mampu menciptakan perubahan dengan memanfaatkan pengetahuan dan kemampuan yang mereka miliki, sehingga melalui BCCF generasi milenial dapat lebih optimal berkontribusi menciptakan perubahan, terlebih generasi milenial memiliki peran penting dalam pengembangan industri kreatif, yang dapat meningkatkan pembangunan ekonomi khususnya di Kota Bandung. Dengan penguasaan keterampilan dalam teknologi digital, keberadaan generasi milenial menjadi sosok yang merepresentasikan dan mendukung terwujudnya masyarakat 5.0 yang memungkinkan manusia untuk memecahkan masalah sosial dengan bantuan teknologi. Dengan begitu, peran generasi milenial dalam mewujudkan masyarakat 5.0 sangatlah besar, khususnya dalam membuat inovasi dan melakukan perubahan di dalam masyarakat berbasis teknologi.
\end{abstract}

Kata Kunci: Generasi Milenial, Masyarakat 5.0, Pelaku Perubahan, BCCF, Industri Kreatif

\section{ABSTRACT}

The millennial generation has an important role in making changes to the surrounding environment. It is undeniable that the involvement of the millennial generation in filling development by creating opportunities and positive change has a big impact on society. The 


\begin{tabular}{|c|c|c|c|c|}
\hline Share: Social Work Jurnal & VOLUME: 10 & NOMOR: 2 & HALAMAN: $127-141$ & $\begin{array}{r}\text { ISSN: 2339-0042 (p) } \\
\text { ISSN: 2528-1577 (e) } \\
\text { DOI: 10.24198/share.v10i2.30637 }\end{array}$ \\
\hline
\end{tabular}

changes created by the millennial generation are clearly felt and seen in the economic and business fields, where change occurs very quickly, creating uncertainty not only in the economic and business fields, but also in various other areas of life. BCCF is an independent community that focuses on encouraging and mobilizing the millennial generation in creating change through efforts to develop creative industries in Bandung City. Judging by using the strength perspective concept, millennials can better understand themselves, and are able to create change by utilizing their knowledge and abilities, so that through BCCF the millennial generation can more optimally contribute to creating change, especially the millennial generation has an important role in the development of the creative industry. , which can increase economic development, especially in the city of Bandung. With mastery of skills in digital technology, the existence of the millennial generation becomes a figure that represents and supports the realization of a 5.0 society that enables humans to solve social problems with the help of technology. That way, the role of the millennial generation in realizing society 5.0 is very large, especially in making innovations and making changes in a technology-based society.

Keywords: Millennial Generation, Society 5.0, Change Actors, BCCF, Creative Industries

\section{PENDAHULUAN}

Pemuda adalah generasi harapan bangsa, agen pembaharu, menduduki posisi strategis, paling berpengaruh untuk mengisi dan melanjutkan proses pembangunan ke arah yang lebih baik pada masa kini maupun masa yang akan datang, sehingga potensi dan peran pemuda harus diaktualkan melalui proses penyadaran terhadap berbagai fenomena sosial yang terjadi di sekitarnya dan perlu dilakukan upaya peningkatan kapasitas, agar para pemuda Indonesia dapat menjadi subjek yang berfungsi dan mandiri dalam rangka menciptakan sejarahnya sendiri.

Generasi muda saat ini dikenal dengan istilah generasi milenial. Menurut data Badan Perencanaan Pembangunan Nasional (Bappenas), terdapat 63 juta milenial atau penduduk usia 20-35 tahun di Indonesia (www.promkes.net., 2019). Sekitar 50,36 persen dari jumlah produktif pada dasarnya merupakan generasi milenial (asumsi: rasio ketergantungan 2015 dan 2017 sama besar). Badan Pusat Statistik (BPS) memproyeksikan generasi milenial menjadi generasi mayoritas dalam strukrur demografis Indonesia. Selain itu, bonus demografi yang di mana, sebagian besar merupakan generasi milenial memiliki kesempatan untuk memajukan Indonesia.
Fenomena menurunnya angka ketergantungan yang terus berlanjut hingga mencapai bonus demografi pada titik terendah, secara tidak langsung akan meningkatkan suplai angkatan kerja (labor supplay), tabungan (saving), dan kualitas umber daya manusia (human capital). Di-era ini pula, akan dikuti dengan berkurangnya kebutuhan penduduk usia tidak produktif, sehingga sumber daya yang dimiliki oleh bangsa Indonesia dapat diahlikan untuk meningkatkan pertumbuhan ekonomi dan kesejahteraan penduduk melalui pembangunan. Dengan begitu, dengan terjadinya bonus demografi di Indonesia memberikan kesempatan untuk menyejahterakan masyarakat Indonesia, dengan cara mendukung dan mendorong generasi milenial untuk dapat berkontribusi dalam pembangunan dengan melakukan perubahan ke arah yang lebih positif.

Hal tersebut didukung dengan pernyataan Gribble dan Bremmer (dalam Hayes 2015), bonus demografi bisa menjadi peluang untuk percepatan pertumbuhan ekonomi suatu negara yang diawali dari perubahan struktur demografi penduduk, dicirikan dengan menurunnya angka kelahiran dan angka kematian penduduk.

Generasi muda pada era sekrang ini disebut milenial sebab kedekatannya dengan millennium dan dibesarkan dalam era digital (Kaifi et al., 2012), sehingga bukanlah hal yang 


\begin{tabular}{|c|c|c|c|c|}
\hline Share: Social Work Jurnal & VOLUME: 10 & NOMOR: 2 & HALAMAN: $127-141$ & $\begin{array}{r}\text { ISSN: 2339-0042 (p) } \\
\text { ISSN: 2528-1577 (e) } \\
\text { DOI: 10.24198/share.v10i2.30637 }\end{array}$ \\
\hline
\end{tabular}

aneh, jika generasi ini memiliki ketergantungan dengan dunia digital. Istilah Generasi Milenial mulai dipakai pada editorial koran besar Amerika Serikat pada Agustu 1993 dan sejak itu istilah generasi milenial mulai dikenal dunia.

Dalam penulisan artikel ini, yang dimaksud dengan generasi milenial adalah mereka yang lahir tahun 1980 dan 2000-an. Hal ini didasarkan pada pemikiran bahwa pada rentang tahun tersebut, sedang terjadi berbagai macam dinamika pada tataran global yang tentu saja akan sangat mempengaruhi kehidupan masyarakat dunia di seluruh belahan dunia tanpa kecuali, yang dikenal dengan istilah globalisasi.

Globalisasi telah membawa pengaruh yang besar pada berbagai bidang kehidupan manusia di dunia. Globalisasi merupakan sesuatu yang tak terelakkan dan memberi manfaat secara ekonomi namun juga implikasi pada banyak aspek kehidupan lainnya secara global dan secara beriringan globalisasi pun memicu terjadinya perubahan pada tataran lokal di masing-masing Negara di dunia, sehingga mendorong masyarakat untuk melakukan berbagai upaya adaptasi atas perubahanperubahan yang terjadi Yuniarto (2014), salah satunya adalah di bidang teknologi.

Dengan demikian, upaya adaptasi harus dilakukan oleh masyarakat dunia agar tidak hanya memperoleh dampak negatif dari terjadinya globalisasi, melainkan dapat ikut serta berkompetisi dan bersaing di tataran global. Berkaitan dengan penggunaan teknologi, hal ini pula memiliki peluang untuk mewujudkan masyarakat 5.0, di mana melalui kemajuan inovasi dalam sains dan teknologi yang luar bias aini, mampu memberikan kontribusi, baik itu di bidang ekonomi, sumber daya alam, bahkam hingga pemecahan masalah sosial. Oleh sebab itu, sangat penting bagi kita untuk memanfaatkan teknologi untuk mendapatkan pengetahuan baru ataupun inovasi baru yang dapat menunjang kehidupan manusia ke arah yang lebih baik.

Generasi milenial dilahirkan di era internet dan komunikasi berkecepatan tinggi yang digukung oleh teknologi, dan terbiasa dengan perubahan dan perkembangan kecanggihan teknologi yang sangat cepat serta merebaknya penggunaan jejaring sosial (Donia Aslanzadeh). Generasi Milenial merupakan generasi yang sangat bergantung dengan teknologi yang digunakan untuk mengakses berbagai informasi dengan cepat. Generasi milenial pun menggunakan teknologi komunikasi instal/ seperti email, SMS, instant messaging dan media sosial seperti facebook dan twitter (Putra, 2016) untuk berkomunikasi dan selalu terhubungan dengan komunitasnya. Dengan berbekal kecakapan dalam menggunakan dan memanfaatkan teknologi, generasi millenial memiliki peluang dan kesempatan yang besar untuk menicptakan inovasi dapat yang berdampak luas bagi masyarakat.

Dengan adanya keberadaan generasi milenial yang lahir di tengah perkembangan teknologi dan sangat dekat dengan teknologi, hal ini bisa menjadi peluang bagi generasi milenia untuk menjadi agen perubahan tentunya dalam mewujudkan masyarakat 5.0, di samping mahir menggunakan teknologi, generasi milenial juga memiliki karakter yang kreatif dan peduli terhadap masalah sosial, dan tentu ini merupakan hal yang baik untuk pengembangan masyarakat 5.0 untuk membantu menyelesaikan masalah di dalam masyarakat secara efisien dan efektif, dan menciptakan kehidupan yang lebih baik lagi.

Peran teknologi saat ini tentunya memiliki dampak yang besar bagi aktivitas manusia, bahkan dapat dikatakan hampir seluruh aktivitas manusia pada wilayah perkotaan khususnya sangat bergantung pada keberadaan teknologi untuk memudahkan pekerjaan dan berbagai aktivitas keseharian, sehingga tidak dapat dipungkiri terlebih bagi generasi milenial yang sangat akrab dan bergantung pada keberadaan teknologi untuk mendukung berbagai aktivitas seharian mereka. Penggunaan teknologi tersebut pula, dimanfaatkan oleh Milenials untuk mengembangkan sebuah produk ataupun inovasi di dalam pekerjaan.

Keberadaan suatu teknologi dapat merubah arah dunia sosial di mana masyarakat hidup. Teknologi dapat merubah persepsi dan pemikiran-pemikiran masyarakat tentang tatanan dunia yang lahir melalui hubungan dialektis antara struktur-struktur makna dan 


\begin{tabular}{|c|c|c|c|c|}
\hline Share: Social Work Jurnal & VOLUME: 10 & NOMOR: 2 & HALAMAN: $127-141$ & $\begin{array}{r}\text { ISSN: 2339-0042 (p) } \\
\text { ISSN: 2528-1577 (e) } \\
\text { DOI: 10.24198/share.v10i2.30637 }\end{array}$ \\
\hline
\end{tabular}

ekpresi-ekpresi teknologi yang nyata. (Krug, 2005: 19).

Berbagai plat form dimanfaatkan oleh generasi milenial untuk dapat mendukung mereka dalam menciptakan perubahan. Hal tersebut berkaitan erat dengan konsepsi internet of things yang merebak sejalan berkembangnya era revolusi industri 4.0 di tataran global. Isu disruption, digital ecosystem dan collaboration menjadi fenomena yang menggambarkan keberadaan generasi milenial sebagai segmentasi yang berpengaruh karena size dan influencing power-nya.

Kondisi tersebut didorong dan didukung pula oleh karakteristik generasi milenial yang memiliki pola dasar yang berbeda, dengan kata lain generasi milenial mencitptakan pola dasarnya sendiri yang berlawanan di tengah kehidupan umum yang terjadi sebelumnya, sehingga cara berpikir generasi milenial dikenal dengan istilah think out of the box yang mengasilkan ide-ide kreatif dan berani melakukan berbagai inovasi pada berbagai bidang kehidupan.

Dalam melakukan aktivitasnya, terdapat dua nilai mendasar yang dimiliki oleh generasi milenial yaitu, Pertama: keinginan untuk bekerja pada perusahaan yang bertanggung jawab secara sosial, yaitu menginginkan bekerja dengan perusahaan yang membantu orang lain merupakan prioritas utama bagi Millennials (Bannon et al, 2011). Kedua, mereka (generasi Millennial) memiliki ketertarikan untuk membantu orang lain dan lebih menyukai organisasi yang digerakkan oleh misi yang sama dengan mereka (Behrens, 2009; Cahil dan Sedrak, 2012). Dengan begitu, generasi Millennial memiliki empati terhadap lingkungan sekitarnya, seperti untuk membantu orang lain.

Keterlibatan generasi milenial pada salah satu aspek kehidupan bermasyarakat yang menonjol adalah pada aspek ekonomi. Generasi milenial menciptakan ekosistem digital yang berhasil membentuk beragam bidang usaha yang didukung oleh kreativitas yang dimiliki oleh generasi milenial, yaitu dengan menggabungkan inovasi dan teknologi, hal tersebut terbukti dengan munculnya perusahaan/bidang usaha online, baik itu pada sektor perdagangan maupun transportasi.
Memahami keberadaan generasi milenial di tengah era globalisasi menjadi penting. Kemajuan yang diciptakan oleh globalisasi, di sisi lain dapat menimbulkan masalah pada kelompok masyarakat tertentu, seperti memunculkan kemiskinan, pengangguran, dan tertutupnya akses rakyat kecil akibat kebijakan pasar bebas dan belum mampunya rakyat kecil untuk dapat ikut bersaing di kancah global Yuniarto (2014), sehingga perlu direspon cepat.

Dalam situasi perkembangan dan perubahan sosial dalam masyarakat yang terjadi begitu cepat, profesi pekerjaan sosial merupakan salah satu profesi yang bertujuan untuk memberikan pertolongan pada kehidupan manusia tentunya harus dapat mengambil peran penting didalamnya dan hal tersebut sekaligus menjadi tantangan tersendiri bagi eksistensi praktik profesi pekerjaan sosial di era digital dewasa ini (Santoso et al., 2018: 274). Terlebih dengan kehadiran generasi milenial sebagai sebuah generasi yang memiliki karakteristik khas dan turut berperan aktif dalam menciptakan perubahan di dalam kehidupan bermasyarakat.

Salah satu komunitas generasi milenial yang telah merespon berbagai perubahan yang terjadi di tengah masyarakat adalah Bandung Creative City Forum (BCCF) sebagai sebuah jaringan komunitas yang mengembangkan industri kreatif di Kota Bandung. Industri kreatif merupakan sub-sektor dari ekonomi kreatif yang dikembangkan oleh pemerintah Indonesia sebagai upaya untuk membangun kekuatan berbasis sumber daya manusia kreatif untuk dapat ikut berkompetisi dalam ekonomi global. Hal tersebut menjadi penting untuk dilakukan, karena ekonomi kreatif akan menjadi lokomotif pertumbuhan ekonomi baru dunia (Sugiarto', 2018)

\section{TINJAUAN KONSEPTUAL}

\section{Generasi Milenial}

Generasi adalah kelompok yang dapat didefinisikan berdasarkan tahun kelahiran, usia, lokasi, dan kejadian penting yang menciptakan kepribadian mereka (Guha, 2010; \& Sutton, 2002). Adanya generasi dapat terjadi oleh 


\begin{tabular}{|c|c|c|c|c|}
\hline Share: Social Work Jurnal & VOLUME: 10 & NOMOR: 2 & HALAMAN: $127-141$ & $\begin{array}{r}\text { ISSN: 2339-0042 (p) } \\
\text { ISSN: 2528-1577 (e) } \\
\text { DOI: 10.24198/share.v10i2.30637 }\end{array}$ \\
\hline
\end{tabular}

peristiwa kehidupan yang signifikan seperti perang, teknologi baru atau transisi ekonomi.

Howe, Neil \& William Strauss (2007) menyatakan bahwa generasi adalah salah satu kekuatan yang paling kuat dalam sejarah. Generasi pun dibentuk oleh peristiwa atau keadaaan yang sesuai dengan fase kehidupan yang ditempati para anggotanya saat itu, seiring bertambahnya usia, mulai dari usia muda, dewasa hingga lanjut usia, dikap dan perilaku mereka semakin penting. Melalui peristiwa tersebut, maka akan membentuk kepribadian, nilai-nilai dan harapan generasi tersebut (Hauw \& Vos, 2010).

Lyons, 2014 menyatakan ciri-ciri dari generasi Millennial diantaranya karakteristik masing-masing individu berbeda, tergantung di mana ia dibesarkan, strata ekonomi dan sosial keluarganya, pola komunikasinya sangat terbuka dibandingkan dengan generasi sebelumnya, pengguna media sosial yang fanatik dan kehidupannya sangat terpengaruh oleh perkembangan teknologi, kehidupannya terbuka dengan padangan politik dan ekonomi.

Millennial merupakan digital native dalam artinya, bahwa hampir semua aktivitas selalu memiliki keterkaitan dengan digital dan internet, termasuk ketika mereka akan mencari lowongan pekerjaan. Howe dan Strauss (2003: 315) berharap bahwa generasi Millennial akan menjadi generasi aktivis internet yang menggunakan kecepatan online untuk membahas secara global masalah politik, militer, dan lingkungan yang menjadi perhatian bersama.

Pembahasan mengenai keterkaitan antara teknologi dan budaya telah dilakukan oleh beberapa ahli (Lievrouw \& Livistone, 2006b), (Krug, 2005a). Krug bahkan menyarankan agar; diri (self), budaya dan teknologi dipandang sebagai elemen yang saling menciptakan dan saling merefleksikan, teknologi bahkan dapat dipandang sebagai suatu budaya (Krug, 2005: xi; 2005: 1-25).

Kreativitas merupakan bagian dari passion generasi Millennial. Banyaknya Millennial yang memutuskan untuk berwirausaha didorong pula oleh kreativitas mereka dalam mengembangkan sebuah inovasi, sehingga kemunculan entrepreneur muda di Indonesia pun semakin tinggi.

Generasi Millenial juga lebih senang bekerja dalam sebuah tim dan lebih toleran dibandingkan dengan generasi-generasi sebelumnya. Kaifi et al., (2012) menemukan fakta bahwa Millennial lebih menyukai budaya organisasi dengan sedikit aturan. Selain itu, generasi Millennial cenderung mempertanyakan segala sesuatu, memiliki harapan yang lebih tinggi terhadap diri mereka (Twenge dan Campbell, 2008b).

Generasi Millennial juga memiliki harapan yang lebih tinggi untuk peluang kemajuan dalam karier mereka, mereka percaya bahwa hal tersebut dapat digunakan untuk memotivasi dan mendorong mereka.

Salah satu karakter dari generasi Millenia/ diantaranya adalah menganggap bahwa keberhasilan dan kegagalan kurang penting, serta sikap pujian untuk apapun dapat mendorong pengembangan harga diri yang tinggi, kebutuhan yang tinggi akan pujian terus menerus, dan rasa kepemilikan yang kuat antara kaum Millennial (Hill, 2002; Twenge, 2010, 2013).

Generasi Millennial juga memiliki keinginan yang kuat untuk menyelesaikan "masalah dunia" dan untuk membantu orang lain (Chambers, 2010; $\mathrm{Ng}$ et al., 2010). Dalam berorganisasi, Hauw dan Vos (2010) menemukan fakta bahwa generasi Millennial lebih bersedia melakukan upaya extra untuk membantu sebuah organisasi agar dapat lebih berhasil.

Karakter generasi Millennial dapat terbentuk, oleh peran lingkungan, yang membentuk ciri-ciri kepribadian dan adaptasi karakter, misalnya teman sebaya, budaya, media, sistem pendidikan semuanya memaikan peran langsung dalam pembentukan dan adaptasi pembentukan karakter generasi Millennial (McCrae et al., 2002).

Era globalisasi yang ditandai dengan hadirnya teknologi komunikasi dan teknologi informasi ini, memiliki pengaruh yang cukup besar kepada generasi Millennial. Dengan adanya teknologi ini, membantu manusia untuk meningkatkan produktivitas, baik itu efisiensi waktu dan tenaga ataupun teknik produksi, 


\begin{tabular}{|c|c|c|c|c|}
\hline Share: Social Work Jurnal & VOLUME: 10 & NOMOR: 2 & HALAMAN: $127-141$ & $\begin{array}{r}\text { ISSN: 2339-0042 (p) } \\
\text { ISSN: 2528-1577 (e) } \\
\text { DOI: 10.24198/share.v10i2.30637 }\end{array}$ \\
\hline
\end{tabular}

sistem kerja dan adanya peningkatan keterampilan dan tenaga kerja (Panjaitan \& Prasetya, 2017). Hal tersebut pula dimanfaatkan oleh generasi Millennial dalam mengembangkan suatu inovasi ataupun produk dengan memanfaatkan teknologi. Generasi Millennial menurut Deloitte (2005) menyatakan bahwa mereka dapat belajar dengan cepat, mengambil tanggung jawab yang signifikan dan memberi kontribusi besar.

\section{Agent of Change}

Setiap perubahan yang direncanakan di dalam masyarakat dapat terjadi jika ada pihak yang menghendaki, memprakarsainya dan menggerakkannya. Pihak-pihak tersebut disebut sebagai agent of change (agen perubahan). Beberapa tokoh mendefinisikan agent of change sebagai seseorang ataupun sekelompok orang yang memperoleh kepercayaan dari masyarakat sebagai pemimpin dari satu atau lebih lembaga kemasyarakatan, dapat memimpin masyarakat dalam menciptakan perubahan pada sistem sosial mereka (Henslin, 2007; PB Horton dan CL Hunt, 1992; Soerjono Soekanto, 2000).

Havelock (1973:8) mengungkapkan bahwa "agen perubahan adalah seseorang yang membantu terlaksananya perubahan". Peran agen perubahan adalah dalam menyebarkan ide-ide sehingga mampu memengaruhi kehidupan masyarakat. Semakin besar dan luas ide yang disampaikan maka akan semakin besar pula ide-ide yang akan disebarluaskan.

O'Gorman 1976 (dalam Nasution, 2009:129) yaitu "agen perubahan memiliki peran manifes sebagai penggerak, perantara dan sebagai pencapai hasil, sedangkan peran laten yaitu sebagai orang yang memobilisir dan selaku organisator."

Peran agen perubahan menurut Havelock (1973:7) adalah sebagai pembantu proses perubahan dan sebagai penghubung (linker), sebagai katalisator dan sebagai pemberi solusi”. Tugas agen perubahan adalah (a). Menumbuhkan keinginan masyarakat untuk melakukan perubahan, (b). Membina hubungan baik dengan masyarakat, (c). Menganalisis masalah masyarakat, (d). Menciptakan keinginan klien untuk berubah, (e). Mengubah keinginan masyarakat menjadi sebuah tindakan nyata, (f). Menjaga kestabilan perubahan, dan (g). Mencapai suatu terminal hubungan.

Kemampuan agen perubahan dalam mendiagnosa kebututuhan dan masalah binaan sangat diperlukan. Hal ini bertujuan agar program yang dijalankan oleh sesuai dengan kebutuhannya. Program yang tidak disesuaikan dengan kebutuhan dan masalah akan mengalami kegagalan bahkan dapat mengalami penolakan dari masyarakat. Maka dari itu mendiadnosa kebutuhan adalah hal yang sangat penting bagi agen perubahan untuk menentukan keberhasilan program. Pernyataan tersebut didukung oleh Rogers (1983:275) bahwa "keberhasilan agen perubahan berhubungan positif dengan seberapa jauh program difusi sesuai dengan kebutuhan binaan". Kemudian pernyataan dari Everet mendapat dukungan dari Nasution (2009:129) bahwa "agen perubahan dalam prosesnya harus mampu memberikan petunjuk mengenai bagaimana mengenali dan merumuskan kebutuhan". Jika masalah dan kebutuhan telah teridentifikasi maka agen perubahan berkewajiban untuk mempersilakan binaannya mencari pemecahan terhadap kebutuhan dan masalah yang dihadapi.

Sebagai pembantu proses perubahan agen perubahan berperan untuk membantu masyarakat dalam mengatasi setiap masalah dan kebutuhannya sehingga permasalahan dan kebutuhan tersebut dapat terselesaikan dan terpenuhi. Membantu Proses perubahan berarti memiliki kewajiban untuk membimbing mulai dari menemukan masalah hingga mencari solusi. Hal ini didukung oleh pendapat Cholisin (2011:5) bahwa "Peran yang dilakukan agen pembaharuan adalah menyediakan pelayanan yang diperlukan oleh masyarakat dan menentukan tindakan yang diperlukan dalam merealisasikan tujuan pembangunan". Pernyataan tersebut menunjukkan bahwa peran agen perubahan sangat penting dalam membangun masyarakat yang lebih baik.

Peran selanjutnya adalah katalisator yaitu sebagai penggerak binaan untuk melakukan perubahan. Hal ini sesuai dengan pernyataan Havelock (dalam Nasution, 2009:129) yang menyebutkan bahwa "peran agen perubahan adalah sebagai katalisator yang 
menggerakkan binaan untuk bergerak menuju perubahan sebagai pemecah masalah, sebagai pembantu proses perubahan".

\section{Tantangan Praktik Pekerjaan Sosial di Era Generasi Milenial}

Sebagai sebuah profesi yang bertujuan memberikan pertolongan pada kehidupan manusia dan mengembangkan potensi yang dimiliki oleh manusia, maka profesi pekerjaan sosial sangat konteks dengan perkembangan dan perubahan sosial yang terjadi dewasa ini yaitu di tengah kehadiran generasi milenial dengan segala kiprah dan upayanya dalam menciptakan perkembangan dan perubahan kehidupan ke arah yang lebih baik dan bersifat out of the box dengan segalah kreativitas dan inovasinya melalui media berteknologi canggih, tentunya hal ini mencirikan karakteristik khas dari generasi milenial.

Setiap perkembangan dan perubahan yang diciptakan oleh generasi milenail dalam rangka merespon berbagai perubahan di tingkat global hingga tingkat lokal tentunya akan berberdampak pada kehidupan manusia, minimal pada kelompok sasaran yang dituju oleh perubahan yang diciptakan. Baik itu perubahan ke arah yang positif sesuai tujuan yang telah dirancang, maupun perubahan yang bersifat negatif sebagai bentuk ketidaksiapan masyarakat di tengah perkembangan dan perubahan yang terjadi. Dalam hal inilah peran pekerjaan sosial dibutuhkan.

Untuk mengetahui hal-hal apa saja yang dapat dilakukan oleh seorang pekerja sosial di tengah terjadinya perubahan sosial yang begitu cepat baik di tingkat global maupun di tingkat lokal, maka hal tersebut dapat dipahami berdasarkan makna praktik pekerjaan sosial yang dirumuskan oleh National Association of Social Workers, yang telah merumuskan pekerjaan sosial sebagai berikut:

"Pekerjaan sosial adalah kegiatan profesional yang membantu individu, kelompok, atau komunitas untuk meningkatkan atau memulihkan kapasitas mereka agar dapat berfungsi secara sosial dan untuk menciptakan kondisi sosial yang menguntungkan bagi tujuan mereka. Praktik kerja sosial terdiri dari penerapan profesional nilainilai, prinsip, dan teknik pekerjaan sosial untuk satu atau lebih tujuan berikut: membantu orang mendapatkan layanan nyata; menyediakan konseling dan psikoterapi untuk individu, keluarga, dan kelompok; membantu masyarakat atau kelompok memberikan atau meningkatkan layanan sosial dan kesehatan; dan berpartisipasi dalam proses legislatif yang relevan." (NASW, 2013).

Seiring perkembangan zaman, di mana perubahan begitu cepat terjadi, praktik pekerjaan sosial pun harus dapat beradaptasi dengan keadaan, yaitu dengan cara melakukan revitalisasi teori, perspektif, model maupun teknik-teknik praktik pekerjaan sosial yang sejalan dengan perkembangan di era generasi milenial seperti saat ini khususnya. Tentunya berbagai upaya tersebut harus sejalan dengan nilai-nilai, prinsip dan etika praktik pekerjaan sosial yang didukung pula oleh upaya pengembangan kapsitas pekerja sosial, sehingga praktik pekerjaan sosial dapat selaras dengan situasi dan kondisi yang ada di tengah tuntutan zaman.

Pekerja sosial dan klien adalah sesama subjek di tengah perkembangan zaman, di mana kondisi kehidupan di dunia berada pada situasi yang disebut VUCA (Voltile / bergejolak, Uncertain / tidak pasti, Complex / kompleks, Ambiouos / tidak jelas) (Rumah Perubahan, 2017), maka tentunya dalam melakukan praktik pekerjaan sosial harus dapat diciptakan strategi yang baik agar tujuan dari proses pertolongan dapat tercapai sesuai rencana tindak yang telah dibuat.

Salah satu strategi yang dipandang sesuai dengan perkembangan situasi dan kondisi yang serba cepat berubah seperti saat ini adalah dengan menempatkan strength perspective sebagai acuan dalam praktik pekerjaan sosial, yaitu dengan memandang bahwa setiap orang mempunyai sumber daya dan kapasitas untuk mengembangkan kehidupan mereka yang belum dimanfaatkan (Salleby dalam Graeme Stuart, 2012: 1). 
Weick et al., (1989) mengungkapkan bahwa dalam strength perspective, klien adalah rekan (partner) dan ahli (expert) dengan pengetahuan dan kemampuannya yang partisipan aktif dalam menciptakan perubahan yang dibutuhkan dan pekerja sosial bukan pemecah masalah (problem-solver), melainkan pada memberdayakan klien dan memantapkan hubungan pertolongan (yang) kolaboratif. Pandangan ini tentunya sesuai jika digunakan dalam situasi dan kondisi di mana perubahan begitu cepat terjadi pada hampir setiap tatanan kehidupan bermasyarakat.

Graybeal, Moore, \& Cohen, (1995) menyatakan prinsip dasar dalam strength perspective yaitu bahwa "individu-individu akan berperilaku baik di masa depan ketika mereka dibantu untuk mengidentifikasi, mengenali dan menggunakan kekuatan-kekuatan dan sumber daya-sumber daya yang tersedia dalam diri mereka sendiri dan dalam lingkungan mereka". Prinsip dasar dalam strength perspective tersebut sangat sejalan dengan nilai-nilai yang ada dan berlaku pada praktik Pekerjaan Sosial yaitu seperti: "self determination, empowerment, worth and human dignity." (Cummins, Sevel, \& Pedrick, 2006).

Situasi kolaboratif antara pekerja sosial dengan klien sangat penting bagi pekerja sosial dalam menjalankan praktiknya, karena pekerja sosial dalam praktik pertolongannya dilakukan atas dasar kerja bersama klien (saling aktif), bukan bekerja terhadap klien (bersifat pasif).

\section{Era Masyarakat 5.0 (Society 5.0)}

Konsep masyarakat 5.0 muncul sebagai tanggapan terhadap kehadiran revolusi industri 4.0, di mana keperluan masyarakat akan lebih mudah terpenuhi dan tentunya membantu mempercepat pekerjaan ataupun aktivitas manusia, sebab dibantu oleh teknologi. Konsep masyarakat 5.0 ini sendiri, sebenarnya sudah dirancang dan disusun dalam Rencana Dasar Sains dan Teknologi oleh Dewan Sains, Teknologi dan Inovasi, dan telah disetujui oleh keputusan Dewan Kabinet pada Januari 2016 (medium.com, 2020). Dengan begitu, melalui masyarakat 5.0 ini akan memudahkan manusia untuk memenuhi dan membantu pekerjaan manusia, dengan memanfaatkan teknologi.
Era masyarakat 5.0 ini sudah diperkenalkan oleh Pemerintah Jepang sejak tahun 2019 lalu. Tepatnya pada tanggal 21 Januari 2019, Perdana Menteri Jepang, yaotu Shinzo Abe, secara resmi meluncurkan roadmap yang dikenal dengan super-smart-society (berpusat pada manusia) dan technology based (berbasis teknologi), lalu pada tanggal 23 Januari 2019, Shinzo Abe mengenalkan konsep tersebut pada forum World Economic (WEF) yang diselenggarakan di Davos, Swiss (medium.com, 2020). Era masyarakat 5.0 ini berlaku bagi masyarakat dunia yang telah menggunakan maupun memanfaatkan teknologi digital pada aktivitas sehari-hari. Tidak hanya itu, masyarakat 5.0 juga memusatkan segala kegiatannya dengan aplikasi digital. Pada artikel Mayumi Fukuyama, pada laman Japan Economic Foundation menyatakan tujuan dari penerapan masyarakat 5.0 ini, yaitu untuk mewujudkan masyarakat yang dapat menikmati hidupnya. Dalam era masyarakat 5.0 ini juga, nilai baru yang diciptakan melalui perkembangan teknologi dapat meminimalisir, adanya kesenjangan pada manusia dan masalah ekonomi di kemudian hari. (republika.co.id, 2017)

Tidak hanya itu, dilansir dari media negara Jepang (globaljapan.world, 2019) ini dari masyarakat 5.0 ini adalah memungkinkan manusia agar lebih cepat memperoleh solusi yang paling cocok dalam memenuhi kebutuhannya. Dengan begitu, manusia dituntut untuk maju dan mengikuti pola perkembangan zaman, sehingga manusia terus untuk mencari informasi-informasi serta menciptakan suatu inovasi baru untuk mendukung kehidupannya.

Masyarakat 5.0 menciptakan berbagai inovasi yang nantinya akan menghilangkan kesenjangan regional, usia, jenis kelamin, pekerjaan dan bahasa, dan tentunya juga memungkinkan individu untuk merancang penyediaan layanan yang beragam sesuai dengan kebutuhan manusia, sehingga memungkinakn untuk mencapai masyakat yang dapat mempromosikan dan menemukan sebuah solusi untuk masalah sosial (medium.com, 2020).

Dengan begitu, dapat disimpulkan bahwa masyarakat 5.0 merupakan sebuah konsep yang di mana memungkinkan manusia untuk 


\begin{tabular}{|c|c|c|c|c|}
\hline Share: Social Work Jurnal & VOLUME: 10 & NOMOR: 2 & HALAMAN: $127-141$ & $\begin{array}{r}\text { ISSN: 2339-0042 (p) } \\
\text { ISSN: 2528-1577 (e) } \\
\text { DOI: 10.24198/share.v10i2.30637 }\end{array}$ \\
\hline
\end{tabular}

menyelesaikan berbagai masalah sosial dengan dukungan teknologi. Selain itu juga adanya era masyarakat 5.0 ini juga sebagai bentuk menyempurnakan revolusi industri 4.0 yang di mana, pada era ini telah membawa masuknya internet terhadap kehidupan manusia, yang menyebabkan adanya gap generation yang disebabkan adanya segementasi penggunaan internet oleh generasi tertentu, namun dengan adanya konsep masyarakat 5.0 ini diharapkan dapat mengubah persepsi tersebut dan tentunya mampu mengalihkan fungsi teknologi untuk membantu manusia dalam berbagai bidang (cohive.space, nd).

\section{METODE}

Metode yang digunakan dalam menulis artikel ini adalah metode deskriptif dengan menggunakan studi literature dengan tujuan agar diperoleh pemahaman yang luas dan mendalam mengenai konsep-konsep dan tataran aktualisasi di lapangan terkait fenomena yang diangkat dalam artikel ini, yaitu bagaimana generasi milenial sebagai pelaku perubahan menjalankan aktivitasnya di tengah masyarakat hingga tercipta perubahan ke arah kehidupan yang lebih baik. Sumber data dalam studi literature ini adalah bersumber dari buku, electronic book, artikel pada jurnal-jurnal nasional maupun internasional, pemberitaan dalam media massa dan berbagai sumber electronic lainnya.

\section{HASIL DAN PEMBAHASAN}

Minat generasi milenial telah menyebar luas, terutama di kalangan pemasar dan pengusaha (Foot, 2001; Hoover, 2009). Dengan kemampuan yang dimiliki oleh generasi milenial seperti kreativitas yang tinggi, dan kepercayaan diri memberikan peluang kepada generasi milenial untuk membuat inovasi yang baru, dan terjun ke dunia industri kreatif yang akan membawa dampak dan perubahan baik terhadap lingkungan, meningkatkan produktivitas dan memperbaiki kondisi perekonomian lingkungan sekitar hingga di tingkat negara.
Saat ini, sudah banyak negara yang sadar bahwa mereka tidak bisa hanya mengandalkan bidang industri sebagai sumber ekonmi mereka di negara mereka, sehingga dengan mengandalkan sumber daya manusia yang kreatif menjadi peluang dan kesempatan untuk membangun perekonomian negara yang lebih baik lagi. Kreativitas manusia berasal dari daya pikirnya, yang kemudian menjadi modal dasar untuk menciptatakan inovasi dalam menghadapi daya saing atau kompetisi pasar yang semakin besar (Purnomo, 2016). Dengan begitu, dengan adanya keberadaan industri kreatif menjadi peluang yang besar bagi negara, tentu hal tersebut tidak disia-siakan oleh Indonesia, untuk meningkatkan perekonomian negara. Ditambah pula, Indonesia memiliki bonus demografi, yang tentunya, hal tersebut dapat di manfaatkan untuk pembangunan ekonomi, dengan menerapkan industri kreatif. Berbicara mengenai bonus demografi maka tidak akan terlepas dari generai milenial, sebab bonus demografi yang terjadi di Indonesia, sebagain besar merupakan generasi milenial.

Industri kreatif merupakan sebuah konsep yang telah muncul lebih dahulu sebelum konsep ekonomi kreatif. Industri kreatif adalah industri yang menghasilkan output dari pemanfaatan kreativitas, keahlian, dan bakat individu untuk menciptakan nilai tambah, lapangan kerja, dan peningkatan kualitas hidup. Definisi industri kreatif menurut Creative Industries Task Force adalah "Creative Industries as those industries which have their origin in individual creativity, skill \& talent, and which have a potential for wealth and job creation through the generation and exploitation of intellectual property and content."

Generasi milenial yang memiliki karakter seperti kepercayaan terhadap dirinya, memiliki kreativitas yang tinggi, dan mampu menggunakan teknologi secara baik, tentulah menjadi sebuah kesempatan untuk terjun ke industri kreatif, untuk mengembangkan dan membuat inovasi produk yang sesuai dengan trend masa kini. Sehingga peran generasi milenial dalam pengembangan industri kreatif sangatlah penting. Pola pikir kreatif yang dimiliki generasi milenial inilah yang sangat diperlukan untuk mengembangkan industri kreatif, yang 


\begin{tabular}{|c|c|c|c|c|}
\hline Share: Social Work Jurnal & VOLUME: 10 & NOMOR: 2 & HALAMAN: $127-141$ & $\begin{array}{r}\text { ISSN: 2339-0042 (p) } \\
\text { ISSN: 2528-1577 (e) } \\
\text { DOI: 10.24198/share.v10i2.30637 }\end{array}$ \\
\hline
\end{tabular}

memiliki dampak besar baik bagi negara, ataupun lingkungan sekitarnya.

Berbicara mengenai industri kreatif, Kota Bandung menjadi kota percontohan yang menunjukkan industri kreatif sebagai perkembangan signifikan dan dapat mempengaruhi trend anak muda di berbagai kota di Indonesia. Kota Bandung merupakan kota kreatif, dengan aktivitas kulturalnya menyatu serta aktivitas ekonomi dan sosialnya, yang menjadikan kota Bandung terpilih sebagai "pilot project" kota kreatif se-Asia Pasifik oleh UNESCO dalam pengembangan industri kreatif di Kawasan Asia Timur dan Asia Tenggara.

Dalam mewujudkan industri kreatif di Kota Bandung, tidak akan terlepas dari peran Bandung Creative City Forum (BCCF), yang hadir membangun industri kreatif di Kota Bandung melalui program-programnya. BCCF yang awalnya diketui oleh Ridwan Kamil ini berperan sebagai simpul pemersatu banyak organisasi yang memiliki tekad untuk memperbaiki kota Bandung.

BCCF adalah organisasi yang didirikan pada tahun 2008 oleh individu dan komunitas kreatif di Kota Bandung, dengan tujuan untuk menumbuhkan kreativitas sebagai upaya untuk memberdayakan potensi ekonomi, dalam rangka meningkatkan kesejahteraan masyarakat lokal, menjaga lingkungan dan menghargai keanekaragaman budaya (Bandung Creative City Forum, (n.d.)).

BCCF merupakan organisasi yang resmi, dan menjelma menjadi sebuah organisasi yang mandiri, dan memberi manfaat bagi masyarakat pada uumumnya dan komunitas kreatif di Kota Bandung khususnya. Dalam kegiatannya, BCCF menggunakan pendekatan pendidikan berbasis kreativitas, perencanaan dan perbaikan infrastruktur kota sebagai sarana pendukung pengembangan ekonomi kreatif, yang menciptakan wirausaha-wirausaha kreatif baik perorangan maupun komunitas.

Generasi milenial memiliki peran yang sangat penting dalam pengembangan industri kreatif, ditambah dengan kondisi Indonesia yang akan mengalami bonus demografi dan akan membawa perubahan bagi negara. Melalui industri kreatif, pembangunan sosial akan terjadi, Midgley (1995) memiliki pandangan bahwa pembangunan sosial merupakan suatu proses perubahan sosial terencana yang dirancang untuk meningkatkan taraf hidup masyarakat, sehingga pembangunan yang dilakukan selalu dilengkapi dengan proses pembangunan ekonomi. Melalui industri kreatif, proses pembangunan yang dilakukan oleh pemerintah memiliki dampak yang cukup besar terhadap pembangunan ekonomi yang tidak akan terlepas dengan pembangunan sosial di dalamnya.

Tercatat sejumlah program yang telah dilahirkan oleh BCCF bekerjasama dengan komunitas kreatif di Kota Bandung, seperti program Helar Festival pada tahun 2008 dan 2009, yang merupakan rangkaian kegiatan perayaan (festival kota) dengan tujuan untuk menampilkan berbagai potensi kreatif yang berkembang di Kota Bandung. Keberadaan Creative Entrepreneur Network (CEN), mewadahi berbagai jenis wirausaha kreatif dari komunitas-komunitas yang di Kota Bandung, sehingga nantinya Creative Entrepreneur Network (CEN) dapat menjadi pusat berjejaring antar pelaku ekonomi kreatif, menyediakan acara-acara untuk berjejaring, membangun keterampilan dan pengetahuan bagi wirausahawan lokal melalui workshop, seminar, klinik bisnis, dan sebagainya.

Pada tahun 2010, BCCF membuat program Semarak Bandung, yang merupakan rangkaian kegiatan kreatif dengan tujuan untuk mengintervensi ruang publik kota Bandung berupa Reka Kota, Nyala Bdg Gedung Merdeka \& Environment Programme (UNEP) \& Kementrian Lingkungan Hidup (LKH) Indoneisa turut mensukseskan program TUNZA International Children and Youth Conference on Environment yang digelar di Gedung Sasana Budaya Ganesha Bandung. Pada tahun 2011, BCCF menyediakan sebuah ruang kreatif yang bernama Bandung Creative Hub (BCH) atau yang sering dikenal sebagai Simpul Space I, yang bertempat di Jalan Ir. H. Juanda No 329 Bandung. Tahun 2012, BCCF meresmikan sebuah ruang publik lain atau Simpul Space yang beralamatkan di Jalan Purnawarman No. 70 Bandung. Ruang kreatif ini tentu memfasilitasi segala macam program yang diusung oleh komunitas seperti pameran, 


\begin{tabular}{|c|c|c|c|c|}
\hline Share: Social Work Jurnal & VOLUME: 10 & NOMOR: 2 & HALAMAN: $127-141$ & $\begin{array}{r}\text { ISSN: 2339-0042 (p) } \\
\text { ISSN: 2528-1577 (e) } \\
\text { DOI: 10.24198/share.v10i2.30637 }\end{array}$ \\
\hline
\end{tabular}

diskusi, workshop, ekskursi, presentasi, pertemuan komunitas dan lain sebagainya.

Pada tahun 2016, kontribusi industri kreatif kepada perekonomian sebesar 7,44\%. Kegiatan industri kreatif ini pun didukung oleh generasi milenial yang bekerja sebagai freelancer mengalami peningkatan sebesar $5,95 \%$ pada tahun 2016, tentu membawa dampak yang cukup besar bagi perekonomian negara. Melihat perluang tersebut, BCCF memanfaatkan potensi kreatifitas untuk meningkatkan kesejahteraan warga dan komunitas, sehingga generasi milenial pun menjadi target pergerakan BCCF dalam mengembangkan program-program yang dirancangnya.

BCCF memiliki andil dalam pembangunan sosial, khususnya di Kota Bandung dengan menggerakkan industri kreatif. BCCF berusaha memanfaatkan potensi kreatifitas untuk meningkatkan kesejahteraan warga dan komunitas. Dengan keberadaan generasi milenial ini menjadi kesempatan BCCF untuk menggerakkan mereka berkontribusi di industri kreatif. Seperti yang kita ketahui bersama, bahwa generasi milenial memiliki peran yang penting dalam industri kreatif. Pola piker yang kreatif yang dimiliki oleh generasi milenial memberikan peluang untuk terjun ke industri kreatif, tentu dengan alasan tersebut menjadikan BCCF tidak ragu untuk melibatkan generasi milenial dalam programnya untuk meningkatkan industri kreatif di Kota Bandung, yang tentunya bekerja sama dengan komunitaskomunitas kreatif yang tergabung dengan BCCF.

Sebagai generasi yang memiliki potensi, untuk menciptakan perubahan di lingkungan sekitarnya. Peran generasi milenial sebagai agen perubahan bukanlah hal yang asing. Cara kerja generasi milenial, yang dapat meningkatkan produktivitas ekonomi, dengan menciptakan inovasi yang baru merupakan hal yang patut dikembangkan, untuk industri kreatif. BCCF yang hadir sebagai wadah untuk berbagai komunitas kreatif di Kota Bandung untuk mengembangkan industri kreatif, tentu memanfaatkan peluang tersebut. Dengan mendorong generasi milenial untuk berkontribusi ke industri kreatif di Kota Bandung, menjadikan generasi milenial sebagai pelaku perubahan di lingkungan sekitarnya, sebab dengan mengembangkan industri kreatif tentulah memberikan dampak yang cukup besar bagi kehidupan masyarakat baik dalam bidang ekonomi, sosial dan lingkungan.

Apa yang telah dilakukan oleh BCCF dengan mendorong generasi milenial untuk terlibat dalam indusrtri kreatif, dari strength perspective, generasi milenial lebih memahami kekuatan yang ada di dalam diri mereka, dan tentunya menggunakan kekuatan mereka, dan segaa sumber daya yang ada pada diri mereka untuk melakukan perubahan terhadap lingkungan sekitar mereka. Pada dasarnya individu unik, memiliki kekuatan dalam dirinya, yang tentu hal tersebut digunakan untuk mengenali dan memahami diri sendiri. Strength perpective mengajak individu untuk melakukan perubahan dengan pengetahuan dan kemampuannya yang partisipan aktif. BCCF yang menggerakkan generasi milenial dengan memanfaatkan pengetahuan dan kemampuan yang dimiliki oleh generasi milenial ini sejalan dengan nilai-nilai yang ada dan berlaku pada praktik pekerja sosial dan tentunya memiliki kebermanfaatan bagi praktik pekerja sosial, sehingga melalui hal tersebut pekerja sosial juga dapat membuat model kerangka kerja praktik pekerja sosial yang baru khususnya intervensi yang akan dilakukan terhadap klien.

Melalui BCCF yang menggerakkan generasi milenial untuk ikut serta melakukan perubahan, dalam prosesnya memberikan peluang untuk memaksimalkan potensi-potensi yang diiliki, dan mendukung entrepreneur generasi muda melalui networking dan patnership yang dibentuk oleh BCCF. Dengan begitu, melalui BCCF yang menggerakkan generasi milenial sebagai agen perubahan yang berkontribusi di industri kreatif menjadikan Kota Bandung menjadi Kota yang kreatif serta mampu membangun industri kreatif yang meningkatkan pembangunan di Kota Bandung, serta mendorong pula masyarakat Kota Bandung dalam pemenuhan kebutuhan hiudpnya dengan membuka usaha kreatif. Sebagaimana yang kita ketahui bersama, bahwa melalui industri kreatif memberikan harapan bagi perekonomian untuk bangkit, bersiang dan meraih keunggulan dalam ekonomi global, serta perlu diketahui pula bahwa dengan industri kreatif, dapat 


\begin{tabular}{|c|c|c|c|c|}
\hline Share: Social Work Jurnal & VOLUME: 10 & NOMOR: 2 & HALAMAN: $127-141$ & $\begin{array}{r}\text { ISSN: 2339-0042 (p) } \\
\text { ISSN: 2528-1577 (e) } \\
\text { DOI: 10.24198/share.v10i2.30637 }\end{array}$ \\
\hline
\end{tabular}

meningkatkan pembangunan ekonomi yang tentunya tidak akan pernah lepas dari pembangunan sosial.

Seperti yang kita ketahui bersama, bahwa konsep masyarakat 5.0 secara tidak langsung sudah diterapkan oleh BCCF dalam menggerakkan generasi milenial terhadap bidang industri kreatif di Kota Bandung. Melalui masyarakat 5.0, mencoba untuk memanfaatkan teknologi untuk menghadapi tantangan berkala global baik itu dalam bidang ekonomi termasuk industri kreatif, sumber daya alam, dan terorisme. Selain itu juga, melalui masyarakat 5.0 ini membawa dampak yang cukup besar dalam merespon masalah yang ada di dalam masyarakat, sebab mencoba untuk memanfaatkan teknologi untuk menjawab dan memecahkan masalah yang ada di dalam masyarakat.

Tidak dapat dipungkiri juga bahwa konsep masyarakat 5.0 ini sebenarnya secara tidak langsung telah diterapkan di Indonesia sendiri, salah satunya adalah dengan memanfaatkan teknologi untuk membuat inovasi maupun memcahkan masalah yang ada di dalam masyarakat. Konsep masyarakat 5.0 ini sendiri pun secara tidak langsung telah diapkan oleh BCCF dalam menggerakkan generasi milenial terhadap indutri kreati di Kota Bandung, yang di mana menggunakan teknologi untuk mewujudkan industri kreatif. Perlu diketahui juga, bahwa industri kreatif ini membawa dampak yang cukup besar, dalam berbagai aspek. Selain itu pula konsep masyarakat 5.0 ini juga berupaya untuk memenuhi berbagai kebutuhan masarakat, dan juga memungkinkan masyarakat untuk hidup secara aktif fan nyama melalui layanan berkualitas tinggi. Dengan adanya keberadaan generasi milenial tentu menjadi peluang dalam mewujudkan masyarakat 5.0 dan ini juga menjadi peluang bagi BCCF untuk menggerakan generasi milenial untuk berkontribusi terhadap industri kreatif.

Tahun 2020, dunia sedang dilanda oleh pandemik COVID-19, yang memakan korban jiwa. Tentu ini menjadi tantangan, bagi Indonesia untuk segera merespon masalah tersebut. Akibat pandemik COVID-19, memberikan dampak yang cukup signifikan terhadap pertumbuhan ekonomi di Indonesia yang mengalami penurunan sebesar $2,3 \%$ yang mengakibatkan aktivitas ekonomi mengalami kendala, seperti daya beli masyarakat meningkat namun pendapat masyarakat menurun. Melihat keadaa tersebut, BCCF pun memiliki andil untuk turut berpartisipasi dalam pandemik COVID-19. BCCF memiliki aksi khusus dengan menjadi bagian dari program ICCN, program yang bernama Aksi Bersama Bantu Sesama (ABBS), melalui website ICCN yang memuat berbagai informasi seperti "bagaimana menginsporaso semangat ke lingkungan sekitar" yang ditujukan atau sasarannya seperti komunitas kreatif dan pekerja kreatif ataupun UMKM dan local brand. Tidak hanya itu, website ICCN ini memberikan informasi seperti apa saja yang bisa kita lakukan selama pandemik COVID-19, untuk melindungi diri sendiri, keluarga, dan sahabat. Dalam situasi seperti ini pula, BCCF hadir melakukan berbagai workshop secara online untuk simulasi dan sosialisasi bagi pelaku UMKM memasuki reaktivasi kegiatan usaha (Indonesia Creative City Network, (n.d.)). Tentu dalam prosesnya pun generasi turut andil di dalamnya, ditambah lagi dengan kondisi seperti ini, memanfaatkan teknologi sangat diperlukan untuk berbagai kegiatan. Melihat hal tersebut, BCCF hadir membawa dampak yang nyata di situasi pandemik COVID-19 ini, dengan memanfaatkan teknologi untuk terus membantu dan meningkatkan perekonomian khusunya di Kota Bandung.

\section{SIMPULAN}

Tidak dapat dipungkiri, bahwa generasi milenial dapat menjadi pelaku perubahan bagi lingkungan sekitarnya. Terlebih lagi bila dilihat dari strength perspective, bahwa setiap individu itu unik, dan memiliki kelebihan, tentu hal tersebut dapat dimanfaatkan oleh generasi milenial untuk menciptakan perubahan dengan menggunakan sumber daya yang ada di dalam diri mereka, seperti kemampuan dan pengetahuan yang dimiliki. Generasi milenial terkenal dengan pola pikirnya yang berbeda dan kreatif, sehingga mampu menciptakan inovasi yang out of the box, ditambah lagi dengan situasi sekarang yang menuntut untuk dapat memanfaatkan teknologi. Dengan kemampuan 


\begin{tabular}{|c|c|c|c|c|}
\hline Share: Social Work Jurnal & VOLUME: 10 & NOMOR: 2 & HALAMAN: $127-141$ & $\begin{array}{r}\text { ISSN: 2339-0042 (p) } \\
\text { ISSN: 2528-1577 (e) } \\
\text { DOI: 10.24198/share.v10i2.30637 }\end{array}$ \\
\hline
\end{tabular}

tersebut, generasi milenial memiliki peranan yang penting untuk terjun ke industri kreatif yang meningkatkan pembangunan ekonomi dan menciptakan perubahan terhadap lingkungan sekitarnya. Hal tersebut dimanfaatkan oleh BCCF sebagai wadah para komunitas kreatif untuk meningkatkan industri kreatif di Kota Bandung. BCCF mendorong generasi milenial untuk terjun ke industri kreatif yang berada di Kota Bandung, sehingga melalui BCCF generasi milenial memiliki peluang untuk menjadi pelaku perubahan, terlebih lagi dalam industri kreatif yang memiliki dampak besar bagi pengembangan ekonomi, sebab ketika berbicara pembangunan ekonomi maka tidak akan terlepas dengan pembangunan sosial. Selain itu juga dengan adanya keberadaan generasi milenial memberikan peluang untuk untuk mewujudkan masyarakat 5.0 untuk mewujudkan kehidupan yang lebih baik dengan memanfaatkan teknologi, dan melalui itu juga masyarakat mampu memecahkan masalah yang ada disekitarnya. Tidak hanya itu BCCF pun hadir di tengah pandemik COVID-19, dan berkontribusi untuk membantu para pelaku kreatif, komunitas kreatif, local brand, dan UMKM untuk reaktivasi kegiatan usaha mereka.

\section{DAFTAR PUSTAKA}

Bandung Creative City Forum (BCCF). (n.d.). Retrieved Juni 5, 2020, from https://bandungcreative.id/

Badan Pusat Statistik. (2018). Statistik Gender Tematik: Profil Generasi Milenial Indonesia. Jakarta: Kementrian Pemberdayaan Perempuan dan Perlindungan Anak.

Bannon, S., Ford, K., \& Meltzer, L. (2011). Memahami Milenium di Tempat Kerja. CPA Journal , 81 (11), 61-65.

Behrens, W. (2009). Mengelola Milenial. Layanan Kesehatan Pemasaran , 29 (1), 19-21.

Cahill, TF, \& Sedrak, M. (2012). Memimpin Tenaga Kerja Multigenerasi: Strategi untuk Menarik dan Mempertahankan Generasi Millenial. Perbatasan Manajemen Layanan Kesehatan , 29 (1), 3-15.

Cummins, L. K., Sevel, J. A. and Pedrick, L. (2006). Social Work Skills for Beginning
Direct Practice: Text, Workbook, and Interactive Web Based Case Studies, $2^{\text {nd }}$ Edition. USA: Pearson.

Cohive. (nd). Society 5.0 untuk Era Baru Proses Banding. Retrieved October 13, 2020, from https://cohive.space/blogs/society-5-0untuk-era-baru-proses-branding/

Deloitte. (2005). Venture Capital Goes Global.

Faadil, Ihsan. (2020). [Society 5.0] Apa Itu Konsep Maysrakat 5.0? Relevankah di Indonesia?. Retrieved October 13, 2020, from:

https://medium.com/@ihsanulfaadil/soci ety-5-0-apa-itu-konsep-masyarakat-5-0relevankah-di-indonesia-2d65a158302

Fukuyama, Mayumi. 2018. Society 5.0: Aiming for a New Human-Centered Society, an article. Japan: Japan Spotlight.

Foot, D.K. (2001). Canadian education: Demographic Change and Future Challenges. Education Canada, 41(1), 2427.

Garybeal, C. T., Moore, V. L. and Cohen, M. B. (1995). The Rransformation of A Social Work Program: A Narrative of Liberation. Reflections: Narratives of Professional Helping. 1 (2), 56-65

Guha, A. (2010). Motivator dan faktor higienis Generasi X dan Generasi Y - ujian teori dua faktor. Vilakshan: Jurnal Manajemen XIMB , 7 (2), 121-132.

Havelock. 1980. Training for Change Agent. America: University of Michigan.

Hauw, S., \& Vos, A. (2010). Perspektif Karier Millenial dan harapan kontrak psikologis: apakah resesi mengarah pada harapan yang lebih rendah? Jurnal Bisnis \& Psikologi , 25 (2), 293-302.

Hayashi, H., Sasajima, H., Takayanagi, Y., \& Kanamaru, H. (2017). International standardization for smarter society in the field of measurement, control and automation. Proceedings of the 56th Annual Conference of the Society of Instrument and Control Engineers of Japan (SICE). Kanazawa, Japan: Institute of Electrical and Electronics Engineers(IEEE). https://doi.org/10.2391 9/sice.2017.8105723. 


\begin{tabular}{|c|c|c|c|c|}
\hline Share: Social Work Jurnal & VOLUME: 10 & NOMOR: 2 & HALAMAN: $127-141$ & $\begin{array}{r}\text { ISSN: 2339-0042 (p) } \\
\text { ISSN: 2528-1577 (e) } \\
\text { DOI: 10.24198/share.v10i2.30637 }\end{array}$ \\
\hline
\end{tabular}

Henslin, James M. (2007). Essential of Sociology: A Down-to-Earth Approach (Sosiologi dengan Pendekatan Membumi). Penerjemah: Kamanto Sunarto. Jakarta: Penerbit Erlangga.

Howe, Neil \& William Strauss. (2003). Millennials Rising: The Next Great Generation. New York: Vintage.

Howe, Neil \& William Strauss. (2007). The Next 20 Years: How Customer Workforce Attitudes Will Evolve. Harvard Business Review. 41-52

Horton, Paul B \& Hunt, Chester L. (1992). Sociology (Sosiologi). Penerjemah: Aminudin Ram. Jakarta: Penerbit Erlangga.

Hoover, E. (2009). The Millennial Muddle: How stereotyping students became a thriving industry and a bundle of contradictions. Chronicle of Higher Education. Retrieved 12 June 2020 from: http://chronicle.com/article/TheMillennial-Muddle-How/48772/.

Indonesia Creative City Network (ICCN). (n.d.). Retrieved Juni 5, 2020, from https://fightcovid19.iccn.or.id/

Kaifi, BA, Nafei, WA, Khanfar, NM, \& Kaifi, MM (2012). Tenaga Kerja Multi-generasi: Mengelola dan Memahami Milenium. Jurnal Internasional Bisnis \& Manajemen , 7 (24), 88-93.

Krug, Steve (2005). DON'T MAKE ME THINK! A Common Sense Approach to Web Usability (2nd ed.). New Riders.

Lyons, S.T., Ng, E.S., and Schweitzer, L. (2014). Changing Demographics and The Shifting Nature of Careers Implications for Research and Human Resource Development. Human Resource Development Review, 13(2), 181-206.

Lievrouw, Leah., Sonia, Livingstone. 2006. Handbook of New Media: Social Shaping and Social Consequences of ICTs. London: Sage Publications Ltd

McCrae, R.R., Costa, P.T., Jr., Terracciano, A., Parker, W.D., Mills, C.J., De Fruyt, F., and Mervielde, I. (2002). Personality trait Development from Age 12 to Age 18: Longitudinal, Cross-sectional and Cross-
Cultural Analyses. Journal of Personality and Social Psychology, 83(6), 1456-1468.

Nasution, Z. 2009. Komunikasi Pembangunan. Jakarta: PT Raja Grafindo Persada.

Panjaitan, Poppy \& Arik Prasetya. (2017). Pengaruh Social Media terhadap Produktivitas Kerja Generasi Millenial. Jurnal Administrasi Bisnis. 48 (1). 173180

Purnomo, Rochmat Aldy. 2016. Ekonomi Kreatif: Pilar Pembangunan Indonesia. Surakarta: Ziyad Visi Media.

Rogers, M. 1983. Difusi Inovasi. Alih Bahasa Abdillah Hanafi. 1994. Tanpa Penerbit.

Rumah Perubahan. (2017, Mei 16). Retrieved Mei 2, 2020, from https://www.rumahperubahan.co.id/blog /2017/05/16/millennials-dan-disruptionjawapos/

Santoso, M. B., Asiah, D. H. S. dan Zainuddin, M. (2018). Tantangan Praktik Pekerjaan Sosial Seiring Perubahan Interaksi Sosial Dalam Masyarakat Modern. Jurnal Prosiding Penelitian \& Pengabdian Kepada Masyarakat. Vol. 5 No. 3. HIm. 272-280.

Soerjono Soekanto. (2000). Sosiologi Suatu Pengantar. Jakarta. PT Raja Grafindo Persada

Stuart, G. (2012, May 30). Retrieved June 5, 2020, from https://sustainingcommunity.wordpress. com/2012/05/30/what-is-the-strengthsperspective/

Sugiarto, E. C. (2018, November 13). Retrieved Juni 4, 2020, from https://www.setneg.go.id/baca/index/ek onomi_kreatif_masa_depan_indonesia

Sutton, Charlotte D. (2002). Generational Differences: Revisiting Generational Work Values For The New Millennium. Journal of Organizational Behavior. 23 (4). 363-382

Twenge, J.M., and Campbell, S.M. (2008b). Generational Differences in Psychological Traits and Their Impact on The Workplace. Journal of Managerial Psychology, 23(8), 862-877

The Report Company. How students are being prepared for Society 5.0, an article. 


\begin{tabular}{|c|c|c|c|c|}
\hline Share: Social Work Jurnal & VOLUME: 10 & NOMOR: 2 & HALAMAN: $127-141$ & $\begin{array}{r}\text { ISSN: 2339-0042 (p) } \\
\text { ISSN: 2528-1577 (e) } \\
\text { DOI: 10.24198/share.v10i2.30637 }\end{array}$ \\
\hline
\end{tabular}

Japan: Intelligence on Global Japan. Adopted from page: https://www.globaljapan.world/artic le/japan-leads-world-in-education-forsociety-5-0/

www.promkes.net. (2019, April 8). Retrieved Juni $\quad 8$, 2020, from https://promkes.net/2019/04/08/bagaim ana-sebenarnya-potret-perilakumillennial-indonesia-saat-ini/

Yuniarto, Paulus R. (2014). Masalah Globalisasi di Indonesia: Antara Kepentingan, Kebijakan, dan Tantangan. Jurnal Kajian Wilayah. Vol. 5 No. 1. HIm. 67-95

Weick, A., Rapp, C., Sullivan, W. P., \& Kisthardt, W. (1989). A strengths perspective for social work practice. Social Work, 34(6), 350-354. 